Contacts

Publisher: Ben Crowe

Editor: Paul Smaglik

Marketing Manager: David Bowen

European Head Office,

London

The Macmillan Building

4 Crinan Street

London N1 9XW, UK

Tel +44 (0) 2078434961

Fax +44 (0) 2078434996

e-mail: naturejobs@nature.com

Naturejobs Sales Director

Nevin Bayoumi (4978)

UK/ RoW/ Ireland:

Matt Powell (4953)

Andy Douglas (4975)

Frank Phelan (4944)

Netherlands/ Italy/ Spain/

Portugal/ Belgium:

Evelina Rubio Hakansson (4973)

Scandinavia: Sille Opstrup (4994)

France/ Switzerland:

Amelie Pequignot (4974)

Natureevents:

Paul Constant (4954)

Production Manager: Billie Franklin

To send materials use London

address above.

Tel +44 (0) 2078434814

Fax +44 (0) 2078434996

e-mail: naturejobs@nature.com

Naturejobs web development:

Tom Hancock

Naturejobs online production:

Ben Lund

European Satellite Office

Germany/ Austria:

Patrick Phelan, Odo Wulffen

$\mathrm{Tel}+498954905711 /-2$

Fax + 498954905720

e-mail: p.phelan@nature.com

o.wulffen@nature.com

US Head Office, New York

345 Park Avenue South,

10th Floor, New York, NY 10010-1707

Tel +1 8009897718

Fax +18009897103

e-mail:naturejobs@natureny.com

US Sales Manager: Peter Bless

US Advertising Coordinator:

Linda Adam

Japan Head Office, Tokyo

MG Ichigaya Building (5F),

19-1 Haraikatamachi,

Shinjuku-ku,

Tokyo 162-0841

Tel +81 332678751

Fax +81332678746

Asia-Pacific Sales Director:

Rinoko Asami

e-mail: rasami@naturejpn.com

\title{
naturejobs
}

\section{Europe goes back to basics}

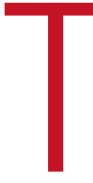

he arguments in support of a single 'European research area' received a fresh airing last month at a meeting in Dublin. Participants heard how the United States is dominating science, with a disproportionate number of highly cited papers - and Nobel prizewinners - now coming from US labs. One factor seemed particularly pertinent - many of the lauded authors and laureates are actually Europeans who have moved across the Atlantic.

A recurring theme at the meeting was the need for more European-led basic research, says Enric Banda, secretary-general of the European Science Foundation (ESF). Currently, funding for basic research varies from country to country within the European Union. And the European Commission's funding mechanism, the Sixth Framework Programme, emphasizes applied research and collaborative projects.

The Dublin meeting, convened by the European Life Sciences Forum and EuroScience, tried to address the issue. One way to combat the brain drain would involve a central European Research Council that would fund basic research across all member countries. Another would be to hold member nations to the commission's goal of increasing each country's research-anddevelopment funding to $3 \%$ by 2010 .

But bringing about such changes is beyond scientists' control. A more realistic approach is to pursue incremental changes from the ground up. The European Young Investigator Awards, which will provide up to $€ 250,000$ (US\$294,000) a year for five years and will be chosen by the ESF next month, represent one such example. But they are just a first step — the earliest possible date that a European Research Council could form is 2007. In the meantime, Europeans can but hope that the Young Investigator Awards lead to highimpact research — and a stop-gap measure against the brain drain.

\section{Paul Smaglik}

Naturejobs editor
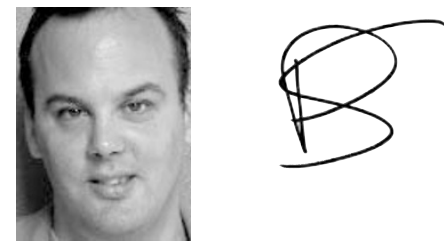

\section{Contents}

\section{REGIONS}

Rhône-Alpes heads

for the summit

\section{WWW.NATUREJOBS.COM}

Career centre

Information on the scientific job market

FOCUS

SPOTLIGHT

RECRUITMENT

ANNOUNCEMENTS

EVENTS 